\title{
Local Colour: \\ Investigating Social Transformations \\ in Transcultural Crime Fiction
}

\section{Rita Wilson}

Summary: Over the last twenty years, Italian "migration literature" has made significant contributions to the redefinition of the country's literary and cultural scene. While the initial phase can best be conceptualized as a generic "micro-system" encompassing canonical genres such as (auto)biography and the Bildungsroman, more recently, narratives of migration have diversified radically, exhibiting a high degree of linguistic and genre experimentation. The defining feature of some of the more successful recent novelists lies in their active engagement with critical social and political issues that concern contemporary Italian society through the vehicle of the crime fiction genre. A case in point is provided by Algerian-born Amara Lakhous, whose four recent novels Scontro di civiltà per un ascensore a Piazza Vittorio (2006), Divorzio all'islamica a viale Marconi (2010), Contesa per un maialino italianissimo a San Salvario (2013) and La zingarata della verginella di Via Ormea (2014) all use strategies of genre hybridization (polyphonic migration narratives blended with giallo and noir structures) to problematize notions of citizenship and cultural identity. This article argues that borrowing the conventions of the giallo/noir enables Lakhous both to provide new insights into shifting constructions of "Italianness"/citizenship in a period characterized by the transition from national to transcultural communities and to accentuate the continuity of the dialogical relationship between the crime fiction genre and contemporary social reality.

In Italy, authors began to incorporate crime fiction elements into "non-genre" works during the 1960s in an operation of genre contamination that was to become a defining trait of the giallo. They produced novels in which the mystery element became an instrument of social analysis of contemporary Italian reality, and that were able to exercise a strong appeal on the Italian reading public. The 
best-known example is Leonardo Sciascia's Il giorno della civetta (1961; The Day of the Owl, 1984), a novel in which the focus is not on the solution of the original crime, revealed in the first few pages, but on the progressive uncovering of the political forces within society (including the connivance of the authorities with illegal organizations), which nullify the investigator's efforts to bring the perpetrator of the crime to justice. Sciascia played a seminal role in firmly establishing the giallo as part of the tradition of impegno/civil responsibility, which characterized postwar Italian cultural production and remains a constant in Italian crime fiction. ${ }^{1}$

In this article, I argue that contemporary writers who are variously described as "migrant," "Italophone," and, more recently, "translingual," ${ }^{2}$ have adopted analogous strategies of genre hybridization to challenge simplistic assumptions about citizenship and national and cultural identity in the context of an increasingly multi-ethnic, multilingual, and multicultural Italian society. Public discourse in Italy is still marked by the negative representation of migrants, generally centred around notions of criminalization and racialization (Dal Lago 50-54) reinforced by an exclusionary discourse in which migrants are categorized as "outsiders" through the use of terms such as extracomunitari and clandestini. Literary fiction, however, follows a different pattern of representation. Since the 1990s, with the rise of the so-called literature of migration, questions of ethnicity and citizenship have gained major visibility in the Italian literary context. In particular, literary narratives have become instrumental in shaping contemporary notions of "national" identity, according to which the adjective "national" is a concept that should never be taken for granted but should instead be constantly renegotiated. Initially, the "first wave" of migrant writing in the 1990s was largely confined to the space of testimonial writing (Parati, Migration Italy 51-70). The shift from testimony and autobiography to more imaginative forms that address the formation of new hybrid subjectivities in recent literary production-experimenting with both the dispersion of different stories and their translation into new forms-reflects the change that has occurred in Italian society. The last two decades have seen the emergence of a large group of foreign-born writers who have introduced new subject positions that are responsible for what is arguably the most significant

\footnotetext{
${ }^{1}$ For more on this, see, for example, Sangiorgi and Telò; Pezzotti; and Pieri.

2 The body of works written in Italian by foreign-born writers is often referred to as "Italophone" or "migrant" literature. Scholars are increasingly challenging the use of these terms with reference, for instance, to the definitions of "first- and second-generation migrant" and "native" writer. See Wilson.
} 
reinvention of Italian literary and cultural geography in recent years. According to sociologist Melita Richter, work such as theirs "announces that we are facing a new epoch in which the 'foreigner' is on the way to becoming perceived as a 'mind' rather than only "hands" (45).

Italianness is represented as a plural concept that involves the voices of its new inhabitants in literary products that appropriate the "national" language and turn it into "a new system of signification" (Parati, Migration Italy 13) that describes the transformation of Italian society as it incorporates people with diverse cultural heritages through narratives of transcultural transitions marked by an ongoing negotiation of identity and change.

According to German philosopher Wolfgang Welsch, cultures are today characterized internally by a pluralization of identities and externally by border-crossing patterns. Previously, homogeneous and separate cultures assumed a new form, "which is to be called transcultural insofar that it passes through classical cultural boundaries" (204). The significance of transculturality as a key concept is emphasized by its link with important phenomena of present-day life: migration, globalization, transnationalism, and the complexities arising from the need to balance multiple cultures in a context of shifting and changing geo-political boundaries along with rapid developments in technology and communication. One of the defining features of the literary production by this new generation of translingual/ transcultural writers is the use of genre as a powerful device for engaging with current political debates about multiculturalism and minority rights in which they advocate what Homi Bhabha has termed "a right to difference-in-equality" (The Location of Culture xvii). Developing this position further, Bhabha proposes "a cosmopolitan community envisaged in marginality" and stresses the political and ethical aspects of the right to symbolic citizenship ("Unsatisfied" 195-196), ${ }^{3}$ which, he argues, offers opportunities for "creating new modes of agency, new strategies of recognition, new forms of political and symbolic representation" (The Location of Culture xviii). In recent transcultural writing in Italy, particular attention is given to questions of (non)belonging for new minority groups in the country, whose access to symbolic citizenship is denied on the grounds of their

\footnotetext{
${ }^{3}$ I use the term "symbolic citizenship" here following Avishai Margalit, who adds the symbolic dimension as the fourth component to T. H. Marshall's tripartite model of citizenship consisting of legal, political, and social dimensions (Margalit 158-159). The right to share in a society's "symbolic wealth," such as, for example, the legal recognition of a minority language, is presented as necessary in order for an individual not to feel excluded, to truly belong in a society.
} 
incompatibility with the rigid, mainstream construction of Italianness, commonly fashioned along the line of colour or religious faith.

The new generation of writers includes those born in Italy either to non-Italian parents or to mixed couples (Gabriella Kuruvilla, Cristina Ali Farah, Gabriella Ghermandi, Igiaba Scego) and those who have been living in the country for several decades (Amara Lakhous, Tahar Lamri, Laila Wadia). Although they opt for genres as diverse as crime fiction (Lakhous) and family sagas (Ghermandi, Scego), what they have in common, in addition to personal biographies inscribed with mobility and multiple cultures, is the deployment of polylingual practices to portray a "genuine polyphony of fully valid voices" (Bakhtin, Problems of Dostoevsky's Poetics 6). In their polyphonic writing, they give agency to the multiple voices that constitute contemporary Italian society-including those marginal voices that had previously been excluded - thus challenging normalized positionings within discursive spaces. A case in point is the work of Amara Lakhous, ${ }^{4}$ which uses the documentary dimension of crime fiction and its analysis of power relations for a critique of ethnic inequalities. Lakhous opts for a popular genre that is easily "accented" (Bakhtin, The Dialogic Imagination 304) as the vehicle to explore the hypothesis that migrant literature is not only an agent of social investigation but can also be an agent of social change. In a recent interview, he explains that his fascination with the giallo stems from the fact that this is a genre that "manages to combine a million other genres." He goes on to declare that he belongs to the

school of Sciascia [rather] than Agatha Christie or other crime writers. Because in Sciascia's novels, the criminal is never an individual, whereas in the classic crime novel, there's an individual, an assassin. That's the first thing. The second thing is that, in a classic crime novel, the criminal is defeated at the end, or killed. That doesn't happen in Sciascia's novels. There's no single guilty person at the end. In my novels, I try not to give too much importance to who is guilty. What I mean is I think that the guilty party is always collective, not individual. ("Full Stop" n.p.)

It is thus no coincidence that one of the three epigraphs that frame his best-selling novel, Scontro di civiltà per un ascensore a piazza Vittorio (2006, translated as Clash

\footnotetext{
${ }^{4}$ Amara Lakhous was born in Algiers in 1970, moved to Italy at the age of 25, and became an Italian citizen in 2008. He has a degree in philosophy from the University of Algiers and a $\mathrm{PhD}$ in cultural anthropology from La Sapienza University, Rome. He has been living in New York since 2014.
} 
of Civilizations over an Elevator in Piazza Vittorio, 2008), is taken from Il giorno della civetta. ${ }^{5}$ The epigraph serves both to locate Lakhous' text as the descendant of a long line of Italian crime fiction rooted in impegno and to signal the start of a process of writing that delves into the ambivalence of truth, its fragmentation and individualization, exposing its gradual disappearance.

All of Lakhous' novels have long titles with locally specific spatial references and ironic intertextual allusions. The latter are bound up not only with the negotiation of authority but also with issues relating to the mediation of values and cultural forms. The title of Scontro explicitly takes its cue from Samuel Huntington's controversial work Clash of Civilisations and the Remaking of the World Order (1996) but is also a tribute to a novel that is considered one of the masterpieces of Italian literature of the twentieth century, Carlo Emilio Gadda's Quer pasticciaccio brutto de via Merulana (1946). Gadda's work-an early example of high literary Italian crime fiction-is undoubtedly a source of inspiration for Scontro. Both authors, albeit in two quite different ways and to different extents, adapt the conventions of the crime fiction genre in order to offer a socially critical portrayal of a specific historical context. The connection between the two texts is made evident by the significant choice of the historical district of Esquilino as the setting for the two stories. The choice of Piazza Vittorio-one of the most populous and multiethnic squares in today's Rome-as the setting for Scontro allows Lakhous to explore and challenge exclusivist constructions of national identities and to emphasize the positive potential of transcultural (minoritation) solidarities. This particular square is paradigmatic in its contemporary role as a showcase of the ongoing social hybridization of Italian society ${ }^{6}$ and is, as Cristina Mazzoni notes, "as emblematic of the new Rome as the she-wolf is of the ancient city" (163). The emphasis on the potential for conflict in new forms of living together in contemporary Rome becomes immediately evident. The anxieties and tensions that accompany the ongoing process of urban hybridization on the local level are framed in the title of the novel through the allusion to Huntington's treatise. The so-called global cultural conflicts that Huntington claims will replace past

\footnotetext{
5 "La verità è nel fondo di un pozzo: lei guarda in un pozzo e vede il sole o la luna; ma se si butta giù non c’è più né sole né luna, c’è la verită” (9).

${ }^{6}$ Evidenced, for example, by the creation of a multicultural orchestra entitled precisely L'Orchestra di Piazza Vittorio. The activity of this orchestra prompted the filming of a critically acclaimed documentary released in 2006 and directed by Agostino Ferrente.
} 
ideological rivalries in contemporary international politics are parodied in the title of Scontro by amending the second part of the original title. The unexpected reference to the dispute over an elevator, a dispute that in fact represents the major source of conflict in the lives of the five immigrant characters and five Italian characters, who either live in or frequent the same building in Piazza Vittorio, points to the book's satirical potential. The two-fold connection with the local dimension of the hybridization process, made explicit in the choice of a particular urban setting and the title's reference to the global discussion of the role of cultural difference, thus highlights the two major components of the larger framework within which the text challenges the mainstream notion of Italianness.

Scontro uses the murder of a shady character nicknamed "Il Gladiatore" in a Roman apartment complex as a pretext to investigate the social relations in this transcultural locality. The structure of the novel is rather complex. The victim's neighbours recount their views on the facts from diverse cultural perspectives, providing a variety of heterogeneous details that reveal grey areas of doubt and open up insights into complex lines of causation, many of which elude closure or neat resolutions. In this transcultural reconstruction, the solution to the main problem is replaced by a new problem, that of the mysterious disappearance of the prime suspect, universally known as Amedeo and thought to be Italian although his real name is Ahmed and he is actually Algerian. ${ }^{7}$ Eleven separate chapters are written in diary form by Ahmed/Amedeo. His diary entries are inserted after each of the rest of the eleven individual chapters. This second group of chapters, upon which the diary chapters comment and expand, are first-person monologues recited in turn by the other characters. All the chapters in this second group are entitled as "The truth according to..." followed by the name of the individual character. The multiplicity of voices and life stories in Scontro is structurally held together by the adoption of elements of the crime novel. These structural elements, such as the murder of one of the building's residents, the investigation, which provides the pretext for the interviews with the rest of the characters, and the solution given in the "truth-telling" chapter by the police inspector (177-185), function as the internal narrative framework securing the smooth integration of the two plot patterns. They also enable Lakhous to introduce a cast of characters from all levels

\footnotetext{
${ }^{7}$ The first time Ahmed walks into the local bar, the owner asks what his name is. Ahmed documents this encounter in the following way: "quando Sandro mi ha chiesto il mio nome gli ho risposto "Ahmed". Ma lui l'ha pronunciato senza la lettera $\mathrm{H}$ perché non si usa molto nella lingua italiana, e alla fine mi ha chiamato Amede', che è un nome italiano che si può abbreviare con Amed" (Scontro di civiltà 139).
} 
of society, including the forgotten, the marginalized, and the disinherited, while also offering a strong sense of place. The presence of a varied cast of characters brings into relief the complexity of linguistic identification and highlights the city as "a vantage point for the study of conceptions of Italian national identity and nationalizing practices" (Sluga 163). By allowing the individual voices to take the floor, Lakhous offers new perspectives and reveals new social dynamics—with a marked emphasis on the conflictual side of these interactions. The complexity at the base of urban social relations is further entangled by the need to negotiate the uncertain articulations of racial, class, and gender differences between both the "natives" and the migrants as well as between the different ethnicities of the migrants.

All of the individual "truth-telling" chapters follow a similar pattern of storytelling in which the character indulges in a series of digressions on various topics, which are interrupted by short comments that defend Amedeo/Ahmed's innocence before the interlocutor. Almost all of the characters reject outright the possibility of Amedeo/Ahmed's immigrant background just as forcefully as they proclaim his innocence, ${ }^{8}$ precisely on account of his linguistic abilities in Italian, his general knowledge of the history and culture of the country, and his particular knowledge of the history and the geography of Rome. The most critical questions related to the issue of symbolic national belonging in the midst of an increasingly ethnically, religiously, and culturally diverse Italian society are summed up right at the start of the novel by Parviz, an Iranian migrant, whose voice is the first to be heard:

Ma poi chi è italiano? Chi è nato in Italia, ha passaporto italiano, carta d'identità, conosce bene la lingua, porta un nome italiano e risiede in Italia? Come vedete la questione è molto complessa. (Scontro di civiltà 15)

Whether the characters express their bewilderment at Italian linguistic heterogeneity or incredulity at the discovery that a foreigner has been able to master the language "meglio di tanti italiani" (Scontro di civiltà 103), these reactions serve

\footnotetext{
${ }^{8}$ To give just a few examples: "È impossibile! Amedeo un assassino! Non crederò mai a quello che mi dice. Io lo conosco come conosco il sapore del Chianti e del gormeh sabzi. Sono sicuro della sua innocenza" (Scontro di civiltà 22); "Il signor Amedeo è un assassino! Questa cosa è assurda. Io sono sicura della sua innocenza" (68-69); "Voglio dire che Amedeo non ha niente a che fare con questo orribile crimine. Amedeo è buono e generoso, 'buono come il pane’ diciamo a Roma” (93-94).
} 
the same textual purpose: the investigation of the nexus between language and national identity. In having as protagonist the culturally hybrid Amedeo/Ahmed, a foreigner who seems to be more Italian than anybody else in the book, Scontro mocks the superficiality of the dominant notion of citizenship/nationality. This dominant notion, in fact, accommodates only those who can be thought of as Italians on the surface, where surface is represented by linguistic knowledge and skin colour. At the same time, Scontro also highlights the strong exclusionary potential of such a notion of belonging. By drawing attention to persistent regional fragmentation, and to internal divisions of the social and linguistic kind between the North and the South, the author draws the reader's attention to the problematic relationship between language and the mainstream notion of nationality.

If Scontro deliberately reconfigures the crime genre model by mixing the sociological intent of Sciascia's writing with the witty linguistic pluralism of Gadda's work, Lakhous' next novel, Divorzio all'islamica a Viale Marconi (2010, translated as Divorce Islamic Style, 2012) goes one step further in the hybridization of the genre by lending the humour of the "commedia all'italiana" to explorations of language, identity, and displacement and framing these questions within the structure of the giallo. Like Scontro, Divorzio contains a web of intertextual references to modern Italian culture, but it is the work of the major Italian director Pietro Germi that comes to the fore here. Divorzio allislamica a viale Marconi is a rewriting of Pietro Germi's film Divorzio allitaliana (1961), a milestone in the genre of Italian film known as "commedia all'italiana" and itself an intertextual, satirical response to a preceding text, Giovanni Arpino's novel Un delitto d'onore (1960). The difference between Lakhous' and Germi's titles is significant: whilst Divorzio allitaliana suggests homogeneity-a divorce Italian-style-Lakhous' work immediately signifies difference and heterogeneity both by associating an Islamic element to the Italian context and by localizing it to Viale Marconi in Rome, one street in one city. While Germi's film narrativizes and problematizes the indissolubility of marriage in 1960s Italy, Lakhous' novel recounts the complexities that exist in an official Islamic divorce from a feminine perspective:

Dopo Scontro di civiltà per un ascensore in piazza Vittorio, che ho scritto per portare uno sguardo sull'Italia, Divorzio all'islamica è uno sguardo al mio paese, alla mia cultura d'origine. Ho usato la stessa metodologia di curiosità. Nella mia cultura, musulmana e khabil, lo sguardo è sempre maschile, è l'uomo, che "vede". Safia, invece, afferma che abbiamo bisogno 
di un'interpretazione femminile del Corano, volevo contrapporre allo sguardo maschile dominante un'altra interpretazione. ("Il primato della leggerezza” n.p.)

The two main characters in the story are Christian, a young Sicilian who speaks perfect Tunisian Arabic and is contacted by the Italian secret services to infiltrate a potential terrorist cell, and Safia, a woman of Egyptian origin who has come to Rome to follow her husband, Said. Once more the setting is crucial, here the crowded and diverse Viale Marconi neighbourhood (in the 15th District of Rome), where the largest Muslim community in the capital resides. It is known as "Little Cairo" because its inhabitants are mainly from northern Africa. Yet again the setting functions as the "locus criminis" in the sense that the description and processing of the geographic, social, and political environment-rather than "the inventories of criminal motives and case histories" (Erdmann 12) — is the central focus of the narrative. Lakhous explicitly speculates on the nature, or, to use Henri Lefebvre's term, the production of social space. It is through this investigation of the connections between the production of social space and the formation of cultural identity that the stories of Safia and Christian meet. Set in the alarmist climate that followed the 2004 Madrid and 2005 London bombings, the novel follows Christian in his undercover role as Issa, a Muslim Tunisian migrant, on his mission to uncover the allegedly imminent Rome bombing being plotted in Viale Marconi. Lakhous makes ironic use of spy novel conventions to once again challenge the dominant view of a monolithic and homogeneous Italian identity. Christian "exits" his Italian identity to inhabit that of a migrant. He adopts the name Issa, shares a flat in Little Cairo with other migrants, and changes his way of speaking: "L'ideale è parlare un italiano con una doppia cadenza, araba, perché sono tunisino, e siciliana perché sono un immigrato che ha vissuto in Sicilia" (Divorzio all'islamica 45).

The change of names from Arabic to Italian and from Italian to Arabic underscores the role of the characters as intercultural mediators. Personal names have been frequently used in literary narratives as dense signifiers in the sense that they may contain in themselves indications about the function of a character or about the way the storyline might develop. The protagonists in Scontro and Divorzio all have double names that reflect their mixed affiliations. From a semiotic perspective, the names act as signs, generating cultural associations that in the case of both male protagonists indicate religious identity. Amedeo/Ahmed's 
name in Italian means "love of God" and in Arabic is a variant of Muhammad and means "praiseworthy." Christian's mission requires him to take on an Arab name, and he, significantly, chooses Issa, which is "il corrispettivo di Gesù per i musulmani” (Lakhous, Divorzio 32). In Safia's case, the change of name is part of a series of empowerment strategies developed by the character. She happily embraces the Italian version of her name (Sofia), not so much because people fail to grasp her name correctly (Divorzio allislamica 25), but more because of the fortuitous coincidence that she resembles the celebrated Italian actress Sophia Loren (who not so coincidentally starred in Vittorio De Sica's celebrated 1964 film Matrimonio allitaliana, providing the reader with yet another ironic intertextual reference to the "commedia all'italiana"). The duality of Christian/Issa and Safia/ Sofia allows each to provide both insider and outsider perspectives on various identities. Because they can acknowledge differing points of view, these characters are not ideologically bound. Christian is Italian, but he also experiences Rome as an outsider, commenting on his experiences in a Sicilian-inflected Italian. Along with his Italian nationality, he has a familial and cultural link to Tunisia through his grandfather. Safia/Sofia's covert political ideas make her an outsider in the Muslim community insofar as she reflects critical opinions on the role of women in Islam. At the same time, she is an outsider in Italy as a foreign woman who wears the veil. The ambiguity imbricated in the renaming and the slippage of one identity into the other is reflected in the novel's narrative strategies, in which both Christian/Issa and Safia/Sofia articulate a dialogue between centre and margin, between Catholic Italy and Muslim northern Africa. Similarly, the fact that both Amedeo/Ahmed in Scontro and Christian/Issa in Divorzio are fluent in Italian and Arabic as well as being well-versed in the discourses of both Mediterranean cultures makes them ideally suited to the role of "intercultural brokers" who could actively contribute to effecting change in both "home" and "host" societies.

In each new story, Lakhous puts the focus on a social issue of great local relevance and global social significance. His most recent novels, Contesa per un maialino italianissimo a San Salvario (2013, translated as Dispute over a Very Italian Piglet, 2014) and La zingarata della verginella di via Ormea (2014), expose the absurdities of the contemporary Italian political and cultural landscape in a period characterized by the transition from national to transcultural communities. The author has stated that he moved to Turin to write these novels because in the second half of the twentieth century this industrial city received massive flows of migrants from the poorest regions of Italy, and his goal was to write "about 
immigration in Italy from within Italy and from outside Italy. [...] To tell the story of the relationship to the Other" ("Full Stop" n.p.). To this end, he creates a protagonist who is himself the product of internal migration: Enzo Laganà, a journalist who works for a local newspaper, is the son of southern Italian parents who immigrated to Turin from Calabria. Enzo is the main protagonist in both novels (perhaps signalling the start of a series). Like the earlier novels, Contes $a$ and Zingarata narrate the dramas of multiple immigrations, of fundamentalism, of a past that is difficult to reconcile, from the multiple perspectives of a culturally diverse cast of characters. Arising as they do from a new Italian reality that needs to be narrated and made understandable, and set in the multiethnic district of San Salvario, these innovative stories are effective examples of a powerfully localized form of crime fiction that functions as a platform for reviewing the social climate and the political and historical forces that actually shape it. In addition, they give us a glimpse into absurd and surreal real-life situations that flow into comedy and thus give life to a new genre: the "giallo alla commedia nera" ("Full Stop" n.p.) or what could be termed the humorous noir.

Set towards the end of 2006 at the time when Romania was about to enter the European Union, Contesa could be described as a state-of-the-nation narrative reflective of today's reality as regards migrants, multi-ethnicity, and new marginality. When four Albanian migrants are murdered on the same day and his editor demands a story, Enzo concocts a feud between Albanian and Romanian criminal gangs. The editor publishes it on the front page and then, when three Romanians turn up dead, demands an interview with the "Deep Throat" that Enzo invented as his source. Enzo turns to his old actor friend Luciano, who gives a phone interview in the guise of an Albanian crime boss. Naturally, that, too, makes the headlines, and Enzo and Luciano need to invent more anonymous sources to prevent the original story from being revealed as fraudulent. In the meantime, Enzo gets embroiled in an unrelated incident involving his upstairs neighbour Joseph, a Nigerian with a pet piglet named Gino. Someone allowed Gino (who wears a Juventus scarf in support of the local soccer team) to run free through the neighbourhood's local mosque, intensely angering Turin's Muslim community, and Enzo soon finds himself acting as mediator between Joseph, the local Muslim community, animal welfare activists, and the local "nativist" group calling itself "Padroni a casa nostra," who intend to exploit Gino's "Italianness" for their own aims. As Enzo desperately digs deeper into the circumstances of the murders, trying to keep his lies from collapsing around him, it emerges that the 
real reason for the killings has to do with a money-making scheme of the 'ndrangheta, the powerful Calabrian organized crime syndicate, which has the habit of "infecting" a neighbourhood before "cleansing" it in order to rake in profits on new property developments. When Enzo offers his newspaper an explosive dossier on the activities of the criminal organization, compiled by the "real" Deep Throat, he is told he would be better off following the story of Gino the pig, who, unlike the foreigners who have invaded San Salvario, is "very Italian" and needs to be rescued from a dreadful fate. The murders remain unsolved, but Enzo's investigation uncovers the "truth" of contemporary Italy: a society pressured on the one side by deeply traditional forms of corruption, and on the other by the imperatives of multiculturalism and globalization.

This "truth" is further scrutinized in the second novel set in Turin, in which the same reporter is given an investigative role. Based on a true story, in which two young Roma men were (falsely) accused by a fifteen-year-old girl of rape, Zingarata is an invitation to reflect on how atavistic prejudices continue to foment intercultural conflict, resulting in violent incidents of intolerance and racism. Lakhous problematizes the intrinsic perceived otherness of the Roma - their representation by the media as social outcasts in Italian cities - and functionalizes their role in the novel to allow them to be used as a symbol for an alternative citizenship. Texts such as Contesa and Zingarata, positioned inside national cultures but on the border of where the foreign meets the familiar, have important implications for our understanding of intercultural exchanges more generally. Lakhous uses the hybrid genre of the humorous noir to read the territory as a space of constant conflict among individuals, groups, social classes, genders, and generations. With the continuous emergence of new subjects, new groups, and new migrants that need a space within the city, we need to ask ourselves: to whom does the city belong? It is precisely on this question that Lakhous' stories hinge. By redefining the urban context as one in which the spaces of "citizenship" are bordered by liminal sites inhabited by "visible" migrants, he shows the impossibility of reliable, definitive, reassuring answers. His representations of marginal and marginalized characters contest both the centre views and those of the periphery, challenging those discourses of nationalist "place-making" that are based on the idea that communities, peoples, and cultures are inextricably and naturally linked to national territories, where people who do not belong have to be excluded. The perceived gap between "immigrant" and "citizen" involves a view, subtle and unconsciously rooted in the minds of natives, that immigrants are ontologically "out of place," in that they 
unsettle the ideal order based on division into nations and on the "natural" origins of such nations that share language, culture, and traditions, even if globalization and the increase of immigrants in Western Europe renders this construct ever less adequate for representing reality.

While none of Lakhous' protagonists are detectives in any conventional sense, they do investigate: not only the fictional crime but, more importantly, how to dismantle stereotypes and prejudices that go to the roots of the racist attitudes of many Italians. The problems of racism and oppression that emerge as part of the "machinations of the mystery plot" (Merivale and Sweeney 2) cannot be thought through in the personal, individualistic terms that conventional crime narrative offers, but rather in terms of collective practices that link disparate individual stories. In other words, Lakhous reproduces ideological linkages as rhetorical ones, and by so doing makes it possible for the narrative to investigate larger issues of social justice, including the social processes whereby selected populations are criminalized. These novels can thus be identified as examples of "texts that oppose the status quo, and relentlessly challenge it" (Locatelli 19). As such, these texts are valuable not only because they explicitly pursue ethical and political aims, but also because they seek to engage the reader in the practice of "dialogic reading," that is, the critical and plurivocal hermeneutic activity that polyphonic literature provokes within individuals and among "interpretive communities" (Locatelli 20).

Lakhous uses the crime story genre to explore and challenge dominant conceptions of law, order, and justice from the perspective of social constituencies that have historically found themselves on the "wrong side" of the law. His work exemplifies how the crime fiction genre has become "a vehicle by which to acknowledge and discuss the relentless process of change in urban and sub-urban spaces and their inhabitants' new worries and anxieties" (Rinaldi 123). In this perspective, the humorous noir-this most hybrid of genres - plays an important role as the purveyor of sociological maps. The novels discussed here accentuate the continuity of the dialogical relationship between the crime fiction genre and contemporary social reality. What is more, they survey urban society from a perspective as yet unavailable in previous canonical crime or detective fiction. Typically, they point to the existence of barriers where previous, supposedly neutral narrative points of view discerned no social obstacle or inequality.

Implicit to Lakhous' reading of citizenship is an impulse to transcend its boundaries at the same time as they are constructed, to challenge depictions of Italianness at the same time as they are in a process of evolution. In this openness 
to the present there is always a space left for possible reconfigurations of identity, an ethical impetus to force us to engage with pragmatic issues on a "case by case basis" in order to reach conclusions about the world in which we live, while at the same time highlighting a deferral of closure. The ethical challenge placed on the reader is to attempt to make sense of the "messy complexities" of these transcultural urban scenarios, yet with the ultimate knowledge that such readings must always remain provisional. Perhaps one way of appraising the ethical potential of Lakhous' fiction lies in the sense of "interference" generated in his texts: instead of providing moral guidance, these novels encourage a process of investigation into contemporary Italy and Italianness that cannot be neatly tied up. The ethnic differentiation of the characters and the abundance of metacritical reflections, together with the web of intertextual references to contemporary Italian culture and the reconfiguration of the crime genre model, lead us to the conclusion that Lakhous' work is not only a textual manifestation of the wish to challenge the static notion of Italianness but also, and perhaps more importantly, an invitation for readers to imagine an inclusive, polyphonic literary tradition with the potential to redefine and diversify prevailing structures of meaning and knowledge.

\section{Monash University}

\section{Works Cited}

Bakhtin, Mikhail. The Dialogic Imagination: Four Essays. Trans. C. Emerson and M. Holquist. Austin: U of Texas P, 1981. Problems of Dostoevsky's Poetics. Trans. C. Emerson. Minneapolis: U of Minnesota P, 1984.

Bhabha, Homi K. The Location of Culture. London and New York: Routledge, 1994.

"Unsatisfied: Notes on Vernacular Cosmopolitanism." In Text and Nation. Ed. Laura Garcia-Morena and Peter C. Pfeifer. London: Camden House, 1996. 191-207.

Dal Lago, Alessandro. Non-Persone. Milan: Feltrinelli, 1999. 
Erdmann, Eva. "Nationality International: Detective Fiction in the Late Twentieth Century." In Investigating Identities: Questions of Identity in Contemporary International Crime Fiction. Ed. Marieke Krajenbrink and Kate M. Quinn. Amsterdam: Rodopi, 2008. 11-27.

Lakhous, Amara. Contesa per un maialino italianissimo a San Salvario. Rome: Edizioni e/o, 2013. Trans. Ann Goldstein. Dispute over a Very Italian Piglet. New York: Europa Editions, 2014. . Divorzio all'islamica a Viale Marconi. Rome: Edizioni e/o, 2010. Trans.

Ann Goldstein. Divorce Islamic Style. New York: Europa Editions, 2012. "Full Stop. Interview with Amara Lakhous." Interview by Meredith K. Ray. Full Stop: April 9, 2014.

. "Il Primato della Leggerezza." Interview by Grazia Puliero. Nigrizia: June 17, 2013.

. Scontro di civiltà per un ascensore a Piazza Vittorio. Rome: Edizioni e/o, 2006. Trans. Ann Goldstein. Clash of Civilizations over an Elevator in Piazza Vittorio. New York: Europa Editions, 2008.

. La zingarata della verginella di Via Ormea. Rome: Edizioni e/o, 2014.

Lefebvre, Henri. The Production of Space. Trans. Donald Nicholson-Smith. Oxford: Blackwell-Wiley, 1991.

Locatelli, Angela. "Literature's Version of Its Own Transmission of Values." In Ethics in Culture: The Dissemination of Values through Literature and Other Media. Ed. Astrid Erll, Herbert Grabes, and Ansgar Nünning. Berlin and New York: De Gruyter, 2008. 19-35.

Margalit, Avishai. The Decent Society. Trans. Naomi Goldblum. Cambridge, MA: Harvard UP, 1998.

Mazzoni, Cristina. She-Wolf: The Story of a Roman Icon. Cambridge: Cambridge UP, 2010.

Merivale, Patricia, and Susan Elizabeth Sweeney, eds. Detecting Texts: The Metaphysical Detective Story from Poe to Postmodernism. Pennsylvania: U of Pennsylvania P, 1999.

Parati, Graziella. Migration Italy: The Art of Talking Back in a Destination Culture. Toronto: U of Toronto P, 2005.

Pezzotti, Barbara. Politics and Society in Italian Crime Fiction: An Historical Overview. Jefferson: McFarland, 2014.

Pieri, Giuliana, ed. Italian Crime Fiction. Cardiff: U of Wales P, 2011. 
Richter, Melita. "Women Experiencing Citizenship." In Common Passion, Different Voices: Reflections on Citizenship and Intersubjectivity. Ed. E. Skaerbæk et al. York: Raw Nerve Books Lts, 2006. 36-48.

Rinaldi, Lucia. "Bologna's Noir Identity: Narrating the City in Carlo Lucarelli's Crime Fiction.” Italian Studies 61.4 (2009): 120-133.

Sangiorgi, Marco, and Luca Telò, eds. Il giallo italiano come nuovo romanzo sociale. Ravenna: Longo, 2001.

Sluga, Glenda. "Italian National Identity and Fascism: Aliens, Allogenes and Assimilation on Italy's North-Eastern Border." In The Politics of Italian National Identity: A Multidisciplinary Perspective. Ed. Gino Bedani and Bruce Haddock. Cardiff: U of Wales P, 2000. 163-190.

Welsch, Wolfgang. "Transculturality: The Puzzling Form of Cultures Today." In Spaces of Culture: City-Nation-World. Ed. Mike Featherstone and Scott Lash. London: Sage, 1999. 194-213.

Wilson, Rita. "Cultural Mediation through Translingual Narrative." Target 23.2 (2011): 235-250. 